\title{
Dimensi pembentuk kesadaran identitas keacehan dan citra diri Aceh
}

\section{Constructing dimension of Acehnese identity realization and self image reflection}

\author{
M. Nazaruddin \\ Fakultas Ilmu Sosial dan Ilmu Politik, Universitas Malikussaleh Aceh \\ Kampus Bukit Indah, Jalan Sumatera No.8, Kec. Muara Satu Kota Lhokseumawe, Aceh, Indonesia. \\ Telepon: 064541373 \\ E-mail: nazaruddin_sosiologi@yahoo.com
}

\begin{abstract}
Constructing Dimension of Acehnese Identity was understood as social-historical aspect that has been shaping self-image and self-realization for Aceh people. The dynamic of Aceh People struggle was based on identity realization and world's view as Aceh people. Aceh is widely known by inherent Islamic Identity since the beginning of Hijriyah year. Research conducted by holding interview and literature review. This study aims to bring back the realization of identity and self-image of Aceh people. Aceh people hold to their Islamic identity tightly and use it as a considerable dimension to design their identity development socially and politically. This identity was implemented in social action, social institution, and social value orientation to preserve the Islamic value in Aceh. Self-image in this context was understood as value orientation, social, cultural, political, and economic system with Islamic value and rites was widely understood.
\end{abstract}

Keywords: Acehnese identity, self-image, pride, Aceh, Islam

\begin{abstract}
Abstrak
Pembentuk kesadaran identitas keacehan dipahami sebagai aspek sosio-historis yang telah membentuk cara pandang diri, cara memahami diri dan cara mengenal diri sebagai Orang Aceh. Dinamika perlawanan Aceh dipandang berdasarkan kesadaran identitas dan pandangan dunia sebagai Orang Aceh. Aceh dikenal dengan Identitas Islam yang melekat sejak awal tahun Hijriyah. Metode Penelitian dilakukan dengan wawancara dan studi pustaka. Penelitian ini bertujuan untuk menyadarkan kembali identitas dan citra diri Aceh. Kesadaran Orang Aceh akan identitasnya yang Islami, dengan demikian adalah basis bagi mereka untuk merumuskan model-model perkembangan identitasnya baik secara sosial maupun politik yang kemudian dapat berujud tindakan sosial, institusi sosial dan orientasi nilai yang sekali lagi juga diperuntukkan untuk merawat identitasnya yang Islami. Citra diri dalam hal ini lebih dipahami sebagai basis nilai dan orientasi nilai, sistem sosial, sistem budaya, sistem politik, sistem ekonomi dan nilai-nilai Islam dengan aqidah dan kaidahkaidahnya dipahami terjaring luas.
\end{abstract}

Kata kunci: identitas keacehan, citra diri, harga diri, Aceh, Islam

\section{Pendahuluan}

Perbincangan mengenai dimensi-dimensi pembentuk kesadaran identitas keacehan dipahami sebagai aspek sosio-historis yang telah membentuk cara pandang diri, cara memahami diri dan cara mengenal diri sebagai Orang Aceh. Dinamika perlawanan Aceh, dipandang berdasarkan kesadaran identitas dan pandangan dunia sebagai Orang Aceh. Dimensi-dimensi tersebut adalah nilai-nilai Islam, Kerajaan Aceh Darussalam sampai pada Kerajaan Pasai dan Peureulak, Perang Aceh dengan Belanda, keterlibatan Aceh dalam kerangka kemerdekaan Indonesia.

Kesadaran tentang sejarah masa lalu yang dianggap sebagai milik bersama dapat dipandang sebagai hal yang penting dalam pembentukan identitas individu dan sosial. Menurut Frederik J. Teggert sebagaimana dikutip oleh Sejarawan Ibrahim Alfian, memori kolektif atau sejarah tentang masa lalu adalah harapan dan aspirasi (inspirasi) bagi kebesaran nasional bagi masa depan. Sejarah dalam masyarakat Aceh kini adalah tidak hanya sebagai sesuatu yang secara kolektif diceritakan dan 
diingat-ingat tetapi juga merupakan sesuatu yang mereka bangga-banggakan. Kesadaran sejarah selalu menjadi arena kontestasi bagi pembentukan suatu identitas individu dan sosial (Alfian 2005).

Mengenai orientasi masa lalu dapat dikatakan bahwa Orang Aceh adalah sekelompok masyarakat yang sangat membanggakan kejayaan masa lalu mereka. Sebagaimana dikatakan Ali, bila mereka sedang membicarakan tentang adat-istiadat, agama, politik atau pembangunan di seluruh Aceh, topik pembicaraan selalu dapat dengan cepat dironai oleh cerita tentang kejayaan Sultan Iskandar Muda dari Kerajaan Aceh Darussalam atau Kerajaan Peurelak dan Samudera Pasai (Ali 1999). Demikian juga tentang heroisme dan kegigihan rakyat Aceh melawan Belanda dalam Perang Aceh yang meletus tahun 1873, yang berlangsung selama lebih kurang 70 tahun. Orang Aceh juga orang yang sangat menghormati dan membanggakan tokoh-tokoh masa lalu yang heroik seperti sultan, ulama dan para pahlawannya.

Hal-hal yang biasa diceritakan atau disosialisasikan melalui lisan, tulisan maupun benda-benda sejarah; cerita, nyanyian, hikayat, literatur sejarah, benteng, kuburan, koin mata uang, pelaku sejarah, situs-situs bangunan, dan bangunan yang kemudian menjadi memori dan refleksi bersama yang membanggakan yang bahkan mengarah pada arogansi yang tercermin dalam ungkapan citra diri orang Aceh sebagai "bangsa njang paleng jroeh ban sigom donya" yang artinya "menganggap diri sebagai bangsa yang paling mulia di atas muka bumi ini". Meskipun kadang kala ungkapan semacam ini hanya sebagai joke, namun kalau dipahami ucapan adalah sarana ekspresi jiwa, maka ia adalah pandangan dunia. Begitulah Orang Aceh memandang dirinya.

\section{Perspektif dan Metode Pembahasan}

Pembahasan terhadap dimensi-dimensi pembentuk kesadaran identitas keacehan akan dielaborasi dalam bentuk diskusi deduktif - induktif sehingga kemungkinan pengulangan dari setiap dimensi yang dibahas tidak dapat dihindari demi mengalirnya proses dialog ini. Diskusi ini terutama didasarkan pada bahan-bahan kepustakaan yang berbicara tentang dimensi-dimensi pembentuk identitas keacehan. Data-data sosial dalam konteks kekinian yang telah diamati juga ditampilkan untuk menunjukkan objektifivasi pembahasan.

Sejarah adalah cermin dari sebagian kehidupan karena di sanalah pantulan siapa diri kita, bagaimana dan atas dasar apa diri kita dibentuk. Proses pembentukan diri ini akan menemui kebaruan-kebaruannya. Dalam dunia yang semakin mengglobal saling silang peradaban adalah hal yang akan membentuk dan mengantar kita ke masa depan. Namun manusia dalam menjalani realitas kehidupan juga berbicara dengan sejarahnya, sehinggga sejarah tidak hanya menjadi teman diskusi, namun lebih dari itu bahkan sejarah telah menjadi guru bagi setiap masyarakat dalam menata kehidupannya. Jadi identitas adalah kontinuitas dalam perubahan.

Demikianlah masyarakat Aceh yang bahkan sangat terikat dengan sejarah masa silamnya karena sejarah bagi rakyat Aceh dengan bahasa lain sebagaimana dikatakan oleh Ali sebelumnya, tidak hanya nyanyiannya, tetapi juga adalah cerminannya. Dikatakan juga dikatakan oleh Melalatoa (2005), bahwa untuk memahami Aceh sekarang atau dalam tulisan ini disebut dengan identitas keacehan, selalu memiliki kaitan dengan benang merah ke masa silam, menyentuh akar budayanya, karena kita kenal Orang Aceh umumnya merupakan masyarakat yang sangat sadar sejarah dan memiliki kesadaran kolektif sejarah yang cukup kental dan cenderung berorientasi ke masa lalu.

Argumentasi ini didasarkan pada logika ideografis dari sebuah pendekatan penelitian, dimana dimensi historis sebagaimana telah ditekankan oleh Max Weber yang dikutip oleh Heru Nugroho merupakan hal yang pasti bagi penelitian jenis ini. Bagi Weber, setiap kajian yang dilakukan dalam sosiologi harus memiliki orientasi pada wawasan historis. Tanpa memahami sejarah maka tidak akan mampu menangkap makna dari sebuah dinamika budaya (Nugroho 2004). 


\section{Aceh dan nilai-nilai Islam}

Sejarawan Taufik Abdullah menyebutkan bahwa Islam adalah pembentuk kesadaran identitas keacehan. Proses Islamisasi sudah dimulai sejak zaman Kerajaan Islam Peureulak yang merupakan pusat pendidikan Islam pertama di Nusantara dan Kepulauan Melayu (sekarang berada dalam wilayah Aceh bagian timur) pada abad ke 8, kemudian dilanjutkan oleh Kerajaan Islam Pase (sekarang berada dalam wilayah Aceh di bagian utara) sekitar abad ke 13 dan kemudian disusul oleh Kerajaan Islam Aceh Darussalam (yang kemudian menyatukan seluruh Kerajaan yang ada di wilayah Aceh sebagai mana yang dikenal sekarang) pada akhir abad ke 15 dan permulaan abad ke 16 (Abdullah 1987).

Proses ini telah menjadikan Aceh sebagai suatu wilayah Islam yang kemudian dikenal sebagai negeri "Seuramoe Meukah" (Serambi Mekah). Dalam konteks inilah kemudian Aceh menjadi melekat dengan Islam dan Islam melekat dengan Aceh. Karena proses Islamisasi yang juga menyertakan aspek sejarah, Islam bertransformasi menjadi identitas sosial bagi orang Aceh (Dhakidae 2001).

Islam sebagai identitas sosial masyarakat Aceh terbentuk lewat perjalanan sejarah yang panjang. Menurut Dhofier (dalam Melalatoa 2005), Islam sudah mulai ada di wilayah Aceh sejak abad pertama Hijriah, yang kemudian terus diperkuat sejak zaman Kerajaan Islam Peureulak disusul oleh zaman Kerajaan Islam Pase dan zaman Kerajaan Aceh Darussalam. Karenanya, orang Aceh sangat bangga bahwa melalui mereka dan daerah merekalah agama Islam masuk ke Asia Tenggara. Kebanggaan itu bertambah lagi dengan melekatnya julukan Aceh sebagai "Seuramoe Meukah". Julukan itu tidak saja karena kedalaman nilai Islam terhujam dalam kehidupan Aceh, namun karena ia juga merupakan sebuah kawasan di mana setiap orang dari Nusantara yang akan menunaikan ibadah haji ke Mekkah terlebih dahulu mampir di Aceh untuk memperdalam ilmu agama, begitu juga saat mereka kembali.

Bahkan menurut Melalatoa (2005) tranformasi nilai-nilai Islam melalui proses sosialisasi, enkulturasi dan pendidikan (formal dan non formal), sudah menyentuh berbagai aspek kehidupan di Aceh. Sehingga lewat perjalanan dan pengalaman sejarah yang telah berjalan berabad-abad lamanya itulah nilai-nilai dan kaidah-kaidah Islam terinternalisasi (diresapi) ke dalam diri anggota masyarakat dan tercermin dalam berbagai sistem berfikir dan aspek kehidupan, baik dalam perilaku, sistem sosial, sistem politik, sistem ekonomi, seni, teknologi tradisional. Misalnya dalam hal sistem ekonomi. Di masa lalu seorang pedagang (muge) mengambil hasil pertanian dari petani produsen tanpa transaksi pembayaran terlebih dahulu. Pembayaran itu baru dilakukan dalam waktu yang relatif lama setelah dagangannya laku. Transaksi antara broker dan petani itu hanyalah berdasarkan kepercayaan. Kepercayaan itu timbul karena mereka yakin, antara sesama muslim tidak akan ada yang berbohong atau menipu. Karena itulah Melalatoa secara umum berpandangan bahwa Orang Aceh dikenal sebagai pemeluk agama Islam yang taat, bahkan terkesan fanatik.

Demikian juga dalam kehidupan sosial politik pengaruh tradisi Islam juga kental terlihat misalnya dalam mata uang emas yang dikeluarkan oleh Kerajaan Samudra Pasai dan Kerajaan Aceh tertera ungkapan al-sultan al-'adil (raja yang adil). Konsep 'adil yang tertulis dalam kepingan mata uang emas itu dipahami sebagai bentuk aktualisasi Firman Allah dalam Kitab Suci Al-Quran. Tradisi ungkapan al-sultan al-'adil yang dipopulerkan oleh Kerajaan Samudra Pasai ini bahkan kemudian telah mempengaruhi mata uang Kerajaan-Kerajaan Islam di di Tanah Melayu seperti Melaka, Johor, Trengganu, Keudah, Brunai Darussalam (Alfian 2005).

Apa yang menyebabkan sehingga raja-raja di Pasai yang kemudian diteruskan di Aceh dan raja-raja Melayu lainnya mencantumkan ungkapan al-sultan al'adil pada mata uang mereka? Sejarawan Ibrahim Alfian mengatakan bahwa raja-raja itu berupaya memerintah sesuai dengan kedudukan mereka sebagai raja muslim yang mengikuti perintah Allah. Hal ini, sambung Alfian, adalah sesuai sebagaimana tertera dalam Kitab Tajussalatin (Mahkota Segala Raja) karangan Bukhari al-Jauhari yang ditulis di Istana Aceh Darussalam pada 1603. Dalam kitabnya Jauhari mengutip Surat an-Nahl 
ayat 90 yang artinya "Bahwa Allah Ta'ala memerintahkan kamu akan berbuat adil dan ihsan". Kitab ini kemudian diterjemahkan ke dalam Bahasa Jawa dan menjadi pegangan bagi raja-raja Islam Mataram dengan judul Serat Tajussalatin (Alfian 2005).

Dalam kitab Tazkiratur Rakidin Syekh Abbas ibnu Muhammad atau lebih dikenal dengan sebutan Teungku Syik Kutakareung menyebutkan:

"Adat ban adat hukum ban hukum, adat ngon hukum sama kembar; tatkala mufakat adat ngon hukum, nanggroe seunang hana goga" ("Adat menurut adat, hukum menurut hukum, adat dengan hukum (syara') sama kembar; tatkala mufakat adat dengan hukum, negeri senang tiada huru-hara") (Alfian 1999).

Yang dipahami sebagai adat dan hukum di sini adalah adat sebagai wilayah politik dan pemimpinnya adalah raja sebagai pimpinan politik, sedangkan hukum adalah hukum syara' dan pemimpinnya adalah para alim ulama. Sehingga ungkapan "hana bak gop na bak geutanyoe, saboh nanggroe dua droe raja" yang berarti tiada di orang ada di kita, satu negeri dua raja, memiliki mafhumnya di sini.

Namun satu hal yang perlu diingat dari uraian di atas bahwa aspek syariat Islam sebagai perwujudan dari pesan suci Islam adalah nilai keadilan yang nampak lebih menonjol dalam sejarah perjalan Islam di Aceh. Dimensi keadilan, terutama penegakannya lebih dibebankan pada pemerintah sebagai pemimpin politik dalam penyelenggaraan negara sebagaimana terlihat dalam ungkapan al-sultan al-'adil dalam mata uang mereka. Pemerintah di sini dipahami baru wajib diikuti manakala perintahnya itu bersatu dengan agama sebagaimana yang telah Allah perintahkan dalam ayat-ayatNya, Al-Quran Surat al-"Araf ayat 3 menegaskan, yang artinya "Ikutilah apa yang diturunkan kepadamu dari Tuhanmu dan janganlah kamu mengikuti pemimpin-pemimpin selainNya (pemimpin-pemimpin yang membawa kepada kesesatan). Amat sedikitlah kamu mengambil pelajaran (daripadanya).

Ulama sebagai pemimpin agama lebih kepada kewajiban untuk menjaga agama, baik agama dalam pengertian ajarannya maupun agama dalam pengertian perilaku dan perwujudannya, sehingga para ulama yang disebut sebagai pemegang hukum batin atau nilai-nilai hukum Islam ini juga wajib diikuti perintahnya dan siapa yang tidak patuh akan mendapat bala (mala petaka). Dalam pengertian yang luas inilah Siegel menyebut Orang Aceh sebagai bangsa yang tidak pernah dapat dilepaskan dari "Tali Tuhannya" (Siegel 2000). Model kepemimpinan politik dan agama yang serupa ini masih dapat kita temui dalam unit teritorial terkecil di Aceh yakni gampong. Di setiap gampong di Aceh selalu ada seorang keuchiek sebagai pemimpin politik (adat) dalam satu kampung dan teungku imum sebagai pemimpin agama.

Apa yang telah digambarkan di atas adalah nilai-nilai ideal yang bersifat normatif yang kemudian membentuk identitas Aceh dan dipahami sebagai Islam. Meskipun dalam kenyataan kehidupan sehari-hari, tidak semua dari dimensi ajaran normatif itu berjalan sebagaimana idealnya. Namun, jika nilai-nilai Islam ini dikaitkan dengan kehidupan sosial dan politik di Aceh, misalnya bagaimana membina sebuah keluarga, menjalin hubungan dengan kerabat dan tetangga, berdagang, membina kehidupan dalam satu teritorial (dari kampung sampai negara), ini memang dipahami sangat terkait dengan nilai-nilai Islam.

Dengan demikian dapat dipahami juga bahwa Islam dalam konsepsi Orang Aceh tidak saja berurusan dengan perkara-perkara ibadah yang bersifat ritual-vertikal, baik dalam koteks hubungan individu dan sosial dengan Khaliq (Orang Islam mengenal perilaku ini dengan ibadah mahdhah), tetapi juga berurusan dengan ibadah yang bersifat horizontal dalam perkara-perkara sosial, ekonomi dan politik. Islam telah memberikan landasan nilai yang kuat yang melalui proses sosialisasinya mampu melahirkan institusi-institusi sosial yang berfungsi tidak saja sebagai arena yang fungsional bagi penataan kehidupan sosial di dunia ini, tetapi juga sebagai arena ibadah yang oleh orang Islam disebut dengan 'ammah. Islam memandang jika sesuatu apapun bila dikerjakan dengan landasan dan nilai-nilai Islam, maka itu adalah ibadah. 


\section{Negara Bangsa (Kerajaan Aceh Darussalam)}

"Bahwasanya kita semua satu negeri bernama Aceh,...yakni satu negeri, satu bangsa, dan satu Kerajaan, dan satu 'alam (bendera) dan satu ajaran yakni Islam dengan mengikuti Syariat Nabi Muhammad SAW. atas jalan Ahlussunnah Waljamaah r.a. dengan mengambil hukum dari pada Al-Quran dan Hadis Nabi dan Qias dan Ijma' 'alim ulama ahlussunnah waljamaah r.a. dengan hukum dengan adat dengan reusam dengan qanun yaitu syara' Allah syara' Rasulullah dan syara' kami bernaung di bawah panji-panji syariat nabi Muhammad saw dari dunia sampai akhirat dan dalam dunia sepanjang masa".

Kutipan di atas adalah Pohon Kerajaan Aceh atau landasan filosofis Kerajaan Aceh Darussalam yang ditegaskankan oleh pendiri Kerajaan Aceh Darussalam Paduka Sri Sultan 'Alaiddin Johan 'Ali Ibrahim Mughayat Syah pada 12 Rabiulawal 913 H (Alfian 2005).

Kerajaan Aceh Darussalam dalam catatan Reid (2005) dibentuk pada tahun 1520 oleh Sultan Ali Mughayat Syah ini telah menyatukan seluruh Kerajaan-Kerajaan seperti Pase, Pidie dan KerajaanKerajaan lainnya di wilayah Sumatera bagian utara. Penyatuan ini sekaligus untuk mengusir Portugis dari wilayah-wilayah itu. Kenyataan bahwa Kerajaan Aceh dibentuk dengan semangat untuk mengusir penjajah Portugis dari perairan Selat Malaka yang memenopoli jalur perdagangan laut kemudian telah membentuk karakter tersendiri bagi anak negerinya, karakter bersatu untuk berperang mengusir musuh dan karakter bersatu untuk menguasai perdagangan. Salah satu kesadaran Aceh adalah menyangkut cerita sejarah pasukan armada laut dibawah pimpinan Laksamana Keumalahayati, seorang perempuan yang memimpin perang melawan pasukan tentara Portugis di laut Selat Malaka.

Pembentukan karakter ini menemukan zaman keemasannya pada masa Sultan Iskandar Muda. Pada zaman ini, Aceh diwarnai oleh penaklukan negeri-negeri di sekitar Aceh Darussalam. Tulisantulisan agung dari para pemikir dan para sufi Islam juga bermunculan. Atas dua hal inilah landasan struktur dan kultur dari ideologi Aceh sebagai "Serambi Mekah" semakin menemui bentuknya (Abdullah dalam Alfian 1987). Bagi Aceh kemudian hari, zaman keemasan Iskandar Muda ini menjadi memori kolektif kesadaran sejarah sebagai satu bangsa dan sebagai ikon penting yang selalu diceritakan dan dibangga-banggakan oleh sebagian masyarakat Aceh.

Tinta emas sejarah juga telah mencatat bagaimana kiprah dan sepak terjang Aceh dalam politik dunia internasional. Tersebutlah di mana Aceh telah menjalin hubungan diplomatik dua negara yang telah terbina antara Kerajaan Aceh dengan Kerajaan Oranje sejak Sultan Alauddin Riayat Syah al-Mukammil (1589-1604) mengirim seberkas surat kepada Prins Mauris (pendiri Dinasti Oranje) untuk memberi pengakuan kemerdekaan kepada Belanda dalam perang kemerdekaannya melawan Spanyol. Aceh kemudian bahkan dikenal sebagai negeri pertama dari Timur yang mengakui kemerdekaan Belanda dari Spanyol dan menempatkan Duta Besarnya Abdul Hamid di Negeri Belanda (Alfian 1997:36).

Kemudian pada 1857 telah ditantandatangani pula satu-satunya perjanjian internasional antara Belanda dan negara berdaulat di Nusantara sejak Belanda menapakkan kakinya di Nusantara. Perjanjian itu dikenal dengan Tractat London yang berisi pengakuan atas kedaulatan Negara Aceh oleh Belanda dan perjanjian saling mengakui dan menghormati kedaulatan masing-masing (Reid 2005). Namun 26 tahun setelah Tractat London ini ditandatangani Belanda pun mengirimi Aceh sepucuk surat permakluman perang kepada Kerajaan Aceh pada 1873. Sehingga Ibrahim Alfian dkk (1997) menyebut Tractat London itu hanyalah siasat belaka kaum kolonial Belanda. Secara sepihak Belanda kemudian membuat Tractat Soematera untuk mengesahkan agresi mereka ke Aceh di saat Aceh dalam keadaan lemah. Hal ini terlihat misalnya jauh sebelum agresi Belanda ke Aceh 1873. Sultan Ibrahim pada 1850 pernah meminta kepada Turki untuk menjadikan Aceh sebagai sebuah propinsi dibawah kekaisaran Ottoman. Permintaan itu dijawab sultan Abdul Mejid dengan memperbarui perlindungan kepada Aceh dengan memerintahkan Gubernur Yaman untuk melindungi kepentingan Aceh dan meneguhkan Ibrahim sebagai raja Aceh (Reid 2005). 
Demikian juga dengan hubungan diplomatik yang telah terjalin antara negara Aceh dengan Turki Osmani. Hal ini dapat kita lihat ketika Sultan Aceh 'Ala al-Din Ri'ayat Syah al Kahar (1537-1571) mengirim perutusan Kerajaan Aceh yang dipimpin Husein Effendi untuk meminta bantuan Turki ketika Aceh bertikai dengan Potugis pada petengahan abad ke 16 (Alfian 1977).

Sejarah mencatat Sultan Selim II kemudian mengirim bala bantuan armada laut kepada Aceh sebanyak 15 buah kapal perang dan 2 buah kapal logistik di bawah pimpinan Laksamana Kourtoglu Khizir Reis untuk membantu Aceh dalam berperang dengan Portugis. Dalam rombongan bantuan itu turut dikirim pula ahli bangunan benteng, ahli perkapalan, ahli peralatan logam, ulama dan para perwira militer (Alfian 1977).

Setelah setahun bertugas di Aceh dan Portugis pun telah berhasil diusir, bala bantuan itu pun kembali ke Turki. Namun, atas permintaan Sultan 2 kapal tetap berada di Aceh. Kerja sama AcehTurki pun semakin ditingkatkan. Hal ini nampak terlihat manakala dibukanya Akademi Militer bantuan Turki untuk Aceh yang diberi nama Asykari Bayt al Muqaddas (Soldier of the Holy House). Akademi ini kemudian telah melahirkan sejumlah ahli perang, diantaranya adalah Laksamana Keumalahayati. Seorang perempuan perkasa dari armada laut Kerajaan Aceh Darussalam (Alfian 1977:36).

Demikian juga hubungan persahabatan antara Aceh dengan Inggris yang telah dijalin sejak masa Ratu Elisabeth I. Pada waktu itu Ratu Inggris itu telah mengirim utusannya kepada Aceh yakni James Lancater untuk membina hubungan diplomati ini. Hal yang sama juga telah dilakukan dengan Perancis. Di Prancis sendiri pada waktu hubungan dipomatik ini dijalin beraada di bawah Louis XIII dan di Aceh berada di bawah tahta Sutan Iskandar Muda (Alfian, dkk 1977:37).

Semua peristiwa ini adalah sejarah dan wawasan penting pembentuk kesadaran keacehan. Keutuhan sistem sosial politik yang terbina sedemikian rupa itu meminjam Dhakidhae (2001) adalah dimensi penting bagi identitas keacehan. Ikatan jati diri Orang Aceh dengan kesadaran sejarahnya yang berkaitan dengan keutuhan Aceh baik sebagai sebuah negara Kerajaan yang berdaulat yang bahkan menjadi aktor politik penting di panggung internasional maupun sebagai sebuah bangsa yang identitas utamanya didasarkan pada Islam tidak saja telah menjadi cermin diri tetapi juga telah menjadi citra diri dan orientasi diri Orang Aceh.

\section{Perang Aceh dengan Belanda}

Keutuhan sosial politik Aceh yang sudah dibentuk sejak 1520 akhirnya bertemu dengan Ultimatum Perang Kerajaan Belanda terhadap Kerajaan Aceh Darussalam pada 26 Maret 1873 yang disambut dengan perlawanan Aceh. Perang baru bisa diatasi Belanda untuk sebagian wilayah Aceh tertentu pada tahun 1904 (Alfian, dkk 1977:52). Ultimatum Perang ini menunjukkan bukti bahwa sampai saat itu Kerajaan Belanda tetap mengakui bahwa Kerajaan Aceh Darussalam itu adalah sebuah negara merdeka dan berdaulat penuh yang terpisah dari wilayah-wilayah jajahan lainnya yang telah ditaklukkan oleh Kerajaan Belanda sebelumnya.

Pengakuan itu pun bukan tak berdasar mengingat hubungan diplomatik dua negara telah terbina antara Kerajaan Aceh dengan Kerajaan Belanda sejak Sultan Alauddin Riayat Syah al-Mukammil (1589-1604) mengirim seberkas surat kepada Prins Mauris (pendiri Dinasti Oranje) untuk memberi pengakuan kemerdekaan kepada Belanda dalam perang kemerdekaannya melawan Spanyol. Demikian juga dengan hubungan diplomatik dan perdagangan yang telah terjalin antara dua negara sejak yang telah dimulai sejak abad ke 16 (Alfian 1977:36, Lombard 2007).

Namun 300 tahun kemudian anak cucu Alauddin Riayat Syah ini mendapat balasan yang tidak semestinya oleh anak cucu pendiri Dinasti Oranje Prins Mauris. Muncul dalam wujud kolonialisme-imperialisme, Belanda membuat ujung sejarah Aceh-Belanda berada dalam pusaran perang 70 tahun yang pada gilirannya telah menghancur leburkan Kerajaan Aceh. Aceh kemudian 
menjadi sebagai tanah jajahan Belanda. Bagi orang Melayu peristiwa semacam diibaratkan peribahasa Indonesia yang berbunyi bagai "air susu dibalas air tuba".

Bukanlah situasi perang Belanda-Aceh yang hendak dibicarakan dalam ulasan ini. Namun, yang hendak dipahami secara kritis di sini adalah apakah penjajahan Aceh oleh Belanda merupakan penjajahan Belanda yang terpisah dari Hindia Belanda lainnya (Dhakidae 2001:23-24). Kalau memang penjajahan bersifat terpisah, maka Aceh sejajar dengan jajahan Belanda lainnya seperti Afrika Selatan, Suriname dan tentu saja Hindia Belanda sendiri. Yang jelas perang Aceh dengan Belanda tidak ada kaitannya sama sekali dengan perang-perang yang terjadi di wilayah-wilayah lainnya di Nusantara pada waktu itu. Hal ini bermakna begini karena perang Belanda dan Aceh adalah perang antara dua negara yaitu negara Aceh dan negara Belanda. Bahkan anak negeri di wilayah-wilayah lainnya di Nusantara yang telah ditundukkan oleh Belanda malah ikut dalam rombongan tentara kolonial Belanda dalam masa perang Aceh dengan Belanda (Alfian 1987:180, Alfian 1997:38).

Satu hal yang perlu diceritakan di sini adalah bahwa perang Aceh dengan Belanda adalah perang dua negara berdaulat, namun diantara pasukan tentara Belanda ternyata banyak prajuritnya yang merupakan kelompok etnis asal Indonesia seperti Jawa, Batak, Ambon. Hal ini dapat dilihat dari nama-nama yang dicatat di batu nisan mereka di Kerkof, kompleks kuburan para prajurit Belanda yang meninggal dalam peperangan di Aceh di Banda Aceh. Peristiwa ini wajar terjadi ketika kita memahami bahwa wilayah yang didiami suku Jawa, Batak, dan Ambon adalah negeri-negeri yang telah lama dijajah oleh Belanda sehingga masyarakatnya pun dalam batasan tertentu kemudian juga telah menerima dan menjadi pegawai dari kekuasaan Hindia Belanda. Ketika Belanda hendak menaklukkan Aceh, Belanda terlebih dahulu mengirim utusannya untuk memaksa kehendak mereka secara damai. Karena hal itu tidak berhasil, kemudian sebuah permakluman perang secara resmi kepada Kerajaan Aceh Darusslam dilayangkan. Dua hal Ini juga menunjukkan bahwa sampai saat itu pun Belanda tetap menempatkan Aceh sebagai tanah yang bertuan dan sebuah negara yang berdaulat.

Satu hal yang perlu juga diingat di sini bahwa Sultan Aceh Muhammad Daud Syah tidak pernah menyerahkan kedaulatan Aceh kepada Belanda. Belanda sebelumnya telah menculik permasuri dan putra Sultan dan menjadikannya sebagai tawanan perang untuk memaksa Sultan turun gunung. Hal itu terbukti manakala meskipun telah menyarungkan pedangnya, Sultan tetap menjadi tawanan Belanda. Meskipun telah ditawan Belanda, Baginda tetap masih menjalin hubungan rahasia dengan para pejuang lainnya dan terus mengusahakan bantuan dari Kaisar Jepang Misalnya. Karenanya pada 24 Desember 1907 Sultan terakhir Aceh Muhammad Daud Syah kemudian dibuang ke Ambon oleh Belanda (Alfian 1987:197-198, Alfian 1997:58).

Sultan boleh saja ditawan bahkan dibuang sampai ke Ambon oleh Belanda, namun perjuangan rakyat dan Kerajaan Aceh dalam membela negerinya terus bergelora dalam irama jihad fi sabilillahnya sampai akhirnya bala tentara Jepang datang mengusir mereka pada 1942. Meskipun kedatangan tentara Kaisar Jepang itu dulunya diundang oleh Sultan Muhammad Daud Syah, namun setelah bersama-sama pejuang Aceh mengusir Belanda dari Aceh, Jepang pun mengambil tempat Belanda di Aceh.

Menurut Taufik Abdullah (dalam Alfian 1987) Perang Aceh dengan Belanda yang dimulai sejak 1873 sampai dengan datangnya Jepang pada tahun 1942 dapat dibagi dalam tiga fase penting, yakni: fase I, yang dikenal dengan sebutan perang antara dua negara (negara Aceh tradisional dengan Belanda kolonial) di bawah pimpinan komando Sultan atau yang mewakilinya. Fase II, setelah Sultan mangkat dan dalam (istana) dikuasai Belanda, sedangkan Sultan yang menggantikannya masih di bawah umur, maka perang Aceh melawan Belanda itu lebih sebagai perang dari daerah-daerah di bawah komando para Ulebalang (bangsawan penguasa lokal). Di sini posisi Sultan hanya sebagai pemersatu bukan lagi komando. Fase III, setelah para Ulebalang berhasil ditaklukkan oleh Belanda baik ada yang syahid maupun ada yang bersedia menerima pengaturan kekuasaan baru dengan mengakui kekuasaan kolonial Belanda, maka perang yang lebih 
berdarah dan bersifat semesta yang meluas ke seluruh penjuru Aceh mulai berkecamuk di seluruh Aceh di bawah kepemimpinan para Teungku-teungku (ulama) (Veer 1977, Alfian 1997:52).

Di bawah kepemimpinan para Teungku (Istilah yang digunakan di Aceh untuk menunjuk tokoh agama Islam), perang Aceh mengalami proses ideologisasi dan sakralisasi. Perang tidak lagi hanya dimaknai sebagai membela negeri tetapi menjadi perilaku spiritual dan ibadah yang disucikan. Karenanya, kematian justru menjadi tujuan perang sebab di sanalah ia akan menjadi syuhada Allah untuk mendapat kehidupan bahagia yang hakiki. Berperang untuk membela kehormatan menjadi hal yang membanggakan bagi kesadaran Aceh. Bahkan kematian di medan perang sebagai syuhada menjadi hal yang diidam-idamkan. Semangat perang melawan kolonial Belanda ini kemudian menjadi kenangan yang membanggakan dan terus diceritakan secara turun-temurun (Alfian 1987:105-108).

Proses ideologisasi dan sakralisasi perang Aceh melawan Belanda ini sebagaimana dicatat oleh Ibrahim merupakan perwujudan dari aktualisasi Kitab Suci Al-Quran Surat Al-Haj ayat 39, yang artinya "Telah diizinkan (berperang) bagi orang-orang yang diperangi, karena sesungguhnya mereka telah dianiaya. Dan sesungguhnya Allah, benar-benar Maha Kuasa menolong mereka itu" dan Surat Al-Baqarah ayat 190 "Dan perangilah di jalan Allah orang-orang yang memerangi kamu, (tetapi) janganlah kamu melampaui batas, karena sesungguhnya Allah tidak menyukai orang-orang yang melampaui batas", yang kemudian direproduksi kembali oleh para ulama dalam bentuk Hikayat Perang Sabi yang kemudian disosialisasikan kepada rakyat melalui khotbah-khotbah. Ideologi perang sabil ini sebenarnya telah muncul di Aceh sejak abad XVII.

Makanya kegigihan dan ketangguhan rakyat Aceh dalam berperang melawan Belanda itu dipahami didorong oleh semangat ideologi dan sakralisasi perang yang didasarkan pada keyakinan agama yang telah direproduksi oleh para alim ulama dalam bentuk hikayat prang sabi itu. Sehingga bagi mereka berperang melawan Belanda dipandang sebagai kewajiban Agama (fardhu 'ien) bagi setiap orang dewasa dan kalau meninggal dalam perang ini maka disebut sebagai mati syahid.

Kegigihan dan ketangguhan rakyat Aceh dan tokoh-tokohnya dalam berperang melawan Belanda merupakan suatu fakta sejarah yang juga dapat menjadi 'i'tibar bagi bagi generasi berikutnya. Peristiwa-peristiwa heroik orang Aceh dalam perang Aceh melawan Belanda ini selalu ditempatkan dalam konteks bela negara bela agama. Maka dalam pandangan Orang Aceh berperang dengan Belanda pada waktu itu adalah jihad, sehingga perang itu sendiri menjadi sesuatu yang dirindukan karena itu adalah jalan cepat menuju surga. Jadi perang Aceh itu tidak saja dapat dipahami dalam dimensi politik dan kekerasan, tetapi terutama harus dapat dipahami dalam dimensi Islami dalam termonologi jihad fisabilillah atau perang suci. Sebagaimana telah dijelaskan di muka, hal ini harus dipahami karena bagi Orang Aceh tidak ada pemisahan antara dimensi sosial dan Islam. Keduanya adalah Islami.

Atas semua peristiwa heroik Orang Aceh dalam perang antara Aceh dan Belanda ini sampai-sampai mengundang seorang penulis berkebangsaan Belanda Zentgraaft untuk mengajukan pertanyaannya:...dan adakah suatu bangsa di muka bumi ini yang tak akan menulis tentang gugurnya para tokoh heroik mereka dengan rasa penghargaan yang sedemikian agung di dalam buku sejarahnya?...” Zentgraaft (1997:56).

Catatan sejarah tetang heroisme Orang Aceh ini tidak saja diceritakan, dinyanyikan, dibanggakan, tetapi bahkan dirindukan oleh Orang Aceh. Internalisasi nilai-nilai Islam yang telah digubah ke dalam bentuk nyanyian yang ditanam sejak dari ayunan oleh sang bunda sampai ke tarian-tarian perang dan heroisme Aceh inilah biang keladi dari semua ini. Bahkan kolonial Belanda pada zaman ia berperang dengan Aceh melarang penggugah heroisme ini dibacakan sehingga mereka mencari, menemukan, menyimpan dan bila perlu memusnahkan hikayat perang sabil Aceh. Nyanyiannyanyian penggugah semangat patriotisme Orang Aceh ini juga kembali menemui nasib yang sama ketika TNI secara tidak resmi telah merazia dan melarang supaya nyanyian-nyanyian semacam 
yang terekam dalam album "Nyawong" atau "nyawa" didengarkan di Aceh di zaman perang RI dan GAM (TN 2006).

Semua catatan sejarah ini telah membentuk kesadaran Orang Aceh bahwa mereka adalah sebuah bangsa yang tidak akan bersedia dijajah dan diperintah oleh bangsa lain. Sehingga bagi Dhakidae peristiwa perang Aceh dengan Belanda ini pun diyakini telah membentuk suatu identitas tersendiri bagi Aceh. Identitas sebagai bangsa yang mau diatur apalagi dirumuskan sebagai dijajah oleh bangsa lain baik dalam dimensi kultural maupun struktural (Dhakidae 2001:23-24).

\section{Keterlibatan Aceh dalam revolusi fisik kemerdekaan Indonesia dan gerakan DI/TII Aceh}

Suatu hal yang harus dipahami secara reflektif adalah menyangkut pengakuan Aceh melalui Maklumat Ulama Aceh pada 10 Oktober 1945 untuk bergabung dengan Indonesia yang sudah diproklamirkan sebelumnya pada 17 Agustus 1945 yang tidak lama setelah itu Aceh dan Jakarta kembali bergolak yang persoalannya paling tidak didasarkan pada persoalan sosial politik, ideologi, ekonomi, kekerasan militer yang diidentifikasikan sebagai persoalan penistaan identitas keacehan oleh Jakarta terhadap Aceh (Maklumat Ulama Seluruh Aceh 1945).

Dalam periode revolusi fisik kemerdekaan Indonesia, di mana Aceh telah menceburkan dirinya dalam perjuangan itu. Pengorbanan yang tak terhingga baik materi maupun jiwanya diberikan Aceh untuk melawan agresi Belanda I dan II dan untuk menegakkan Indonesia dengan harapan ada kesesuaian tujuan historis bahkan ideologis antara Aceh dan Indonesia. Periode ini menjadi masa yang sangat penting dan genting bagi hubungan Orang Aceh dan Pemerintah Pusat Republik Indonesia di kemudian hari (Reid 2003).

Aceh sebagai daerah pemodal bagi tegaknya Republik Indonesia, begitu kata Soekarno (Presiden pertama Indonesia), kemudian menemui dirinya bagai terasing di wilayah yang dikenal dengan sebutan Indonesia itu. Dalam periode ini, Aceh kembali bergolak. Namun pergolakan kali ini antara Aceh dan Pemerintah Indonesia. Hal itu meminjam bahasa Abdullah (2003), terjadi ketika keutuhan dari polity lama serta otonomi kultur yang relatif dari masing-masing kelompok sosial (dalam hal ini Aceh) telah dicederai oleh perkembangan politik dan dinamika sosial ekonomi baik pada masa Orde Lama maupun Orde Baru. Tradisi perlawanan terhadap sesuatu yang dirumuskan sebagai "kaphe" yang telah membentuk suatu sikap politik dan corak perkembangan sosial Aceh menemukan bentuknya kembali dalam periode ini (Melalatoa 2005, Abdullah 1987).

Proses pembentukan kesadaran keacehan sudah menjadi identitas sosial dan politik bagi Aceh untuk melawan setiap corak penindasan terhadap Aceh. Karenanya, politik perlawanan Aceh cenderung disandarkan pada kesadaran Aceh yang demikian. Mobilisasi identitas sosial dan politik perlawanan Aceh itu dapat dilihat sebagai politik identitas perlawanan Aceh terhadap segala corak kesewenang-wenangan dan penindasan.

Dalam hal sentralisasi, ketimpangan ekonomi, politik, sosial dan politik kebudayaan Pemerintah RI yang kemudian dicoba redam dengan tindak kekerasan militer dan politik kooptasi ketika Aceh menuntut keadilan dalam makna yang luas yang terjadi di Aceh sejak dasawarsa 1950-an telah banyak menimbulkan korban baik harta, benda, bahkan nyawa yang pada gilirannya dimaknai sebagai bentuk penistaan negara terhadap eksistensi rakyat Aceh yang dikenal sebagai bangsa yang tidak pernah tunduk pada kekerasan dan dominasi bangsa lain.

Bentuk perlawanan Aceh terhadap negara pun kemudian bertambah besar ketika negara dalam upaya meredam gejolak itu tidak peka terhadap harkat dan martabat (kesadaran akan harga diri) Orang Aceh. Pada gilirannya bentuk kesalahan negara dalam meredam gejolak itu menjadi semakin politis maknanya ketika negara lebih menonjolkan kekerasan militer dan menggunakan paham "hancurkan dan kuasai semuanya". Karenanya, peredaman gejolak itu juga sudah menyentuh harkat dan martabat orang Aceh yang lebih hakiki. Tidak hanya itu, dalam buku Demokrasi untuk 
Indonesia yang ditulis oleh Hasan Tiro, peristiwa demikian ia simpulkan dapat terjadi karena memang di antara keluarga bangsa-bangsa yang disebut dengan Indonesia itu tidak ada rasa kebangsaan yang sesungguhnya. Satu-satunya tali ikatan antara rakyat-rakyat di Indonesia kata Tiro adalah Islam, namun sejak Soekarno menyingkirkan Islam dari negara, maka secara langsung telah membawa kepada perpecahan di kalangan bangsa Indonesia yang sedang coba dibina (Tiro 1999).

Sesungguhnya semboyan yang tertera di kaki Burung Garuda sebagai simbol negara Indonesia yakni Bhineka Tuggal Ika sebagai bentuk pengakuan bahwa masyarakat Indonesia memang berbeda tetapi hendak bersatu untuk mencapai cita-cita bersama tidak cukup hanya menjadi hafalan, tetapi ia tidak hanya kenyataan yang harus kita terima dan dirawat, namun secara hakiki harus dimuliakan dengan melindungi dan mengembangkannya. Konsep Bhinneka Tunggal Ika tidak cukup hanya menjadi politik identitas dalam dimensi mobilisasi dan produksi kekuasaan politik, tetapi juga harus dapat dirasakan oleh setiap komponen yang dilibatkan di dalamnya sebagai sebuah negara Indonesia yang lebih besar dapat memberikan manfaat bagi mereka bila dibanding dengan yang dapat diberikan oleh negara lama tempat mereka dulunya telah membina indentitasnya yang juga hendak dirawat dalam keindonesiaan sekarang ini.

Dengan demikian sampailah kita pada pertanyaan kritis lanjutan yang perlu juga direfleksikan secara mendalam sebagaimana ditulis juga oleh Reid (2005), yaitu atas dasar apa dan bagaimana Aceh harus tetap menjadi bagian dari Indonesia atau menjadi dirinya sendiri. Meskipun demikian, Aceh dalam konteks ini dipahami tidak dalam pengertian revivalistik yang seutuhnya, namun lebih dimaknai dalam pengertian transformatif. Kontinuitas yang disesuaikan dengan konteks zaman. Kesadaran Orang Aceh akan identitasnya yang Islami, dengan demikian adalah landasan bagi mereka untuk merumuskan model-model perkembangan identitasnya baik secara sosial maupun politik yang kemudian dapat berujud tindakan sosial, institusi sosial dan orientasi nilai yang sekali lagi juga diperuntukkan untuk merawat identitasnya yang Islami.

\section{Simpulan}

Betapa melekatnya Orang Aceh pada sejarah masa lalu membentuk identitas diri masyarakat Aceh yang lekat akan perjuangan. Sejarah membekali ingatan mereka dengan catatan kegemilangan, kemakmuran, dan kesejahteraan yang pernah dikecap di masa lalu, juga penderitaan yang mereka dapat semasa perang. Citra diri dan harga diri Aceh yang demikian baik dalam kategori catatan kegemilangan masa lalu maupun dalam kategori memori ketertindasan kolektif terutama zaman peperangan dapat saja digunakan untuk menggugah dan memobilisasi kesadaran Orang Aceh untuk menuntut posisi mereka ditempatkan secara sewajarnya dalam ruang-ruang sosial politik kebangsaan Indonesia.

Citra diri dalam hal ini lebih dipahami sebagai basis nilai dan orientasi nilai, sistem sosial, sistem budaya, sistem politik, sistem ekonomi Orang Aceh sebagaimana telah dipaparkan di atas. Di Aceh sebagaimana telah diperlihatkan di atas, nilai-nilai Islam dengan aqidah dan kaidah-kaidahnya dipahami terjaring luas dan merasuk dalam semua unsur sistem sosial budaya Aceh lainnya. Sehingga bagi Orang Aceh segala dimensi tidakan sosial keacehan dianggap sebagai sesuatu yang Islami.

Sistem sosial politik yang utuh dalam bentuk Kerajaan Aceh Darussalam dan peranannya sebagaimana telah dipaparkan di awal ulasan, merupakan puncak dari rumusan identitas keacehan yang telah menjadi basis dari kesadaran sejarah politik Aceh yang tidak hanya memberi citra pada diri mereka sebagai sebuah bangsa dan negara berdaulat di muka bumi tetapi juga sebagai bangsa dan negara yang ditheu ban sigom donya (aktor penting dalam percaturan politik internasional).

Citra Aceh sebagai daerah pemodal utama tegaknya Indonesia baik di masa revolusi fisik maupun di zaman "pembangunan" bahkan menjadi kesadaran kolektif Aceh bahwa merekalah pemilik utama saham Republik ini. Sebaliknya, sejarah juga mencatat bahwa identitas Orang Aceh juga 
penuh dengan cerita duka yang terakumulasi dalam satu tanda yang disebut juga dengan identitas Aceh yang tertindas.

Dari kesadaran identitas yang tertindas ini kemudian telah melahirkan para patriotik karena mereka telah menampilkan diri sebagai pejuang yang diidentifikasi sebagai syuhada bagi kelompok mereka. Reproduksi ketertindasan identitas kemudian telah mereproduksi para martir yang dicitrakan sebagai patriot bagi mereka yang pada gilirannya menjadi basis kesadaran tentang citra diri Orang Aceh sebagai orang pantang ditindas.

Kemampuan memahami dimensi-dimensi pembentuk identitas keacehan (kesadaran akan citra diri dan harga diri Orang Aceh), baik identitas sosial budaya maupun politik dan pengalaman kolektif Aceh yang sudah menyejarah itu sangat dibutuhkan ketika kita hendak memahami keacehan lebih jauh dalam dimensi dan konteks sosial politik.

\section{Daftar Pustaka}

Abdullah T (2003) Pejuang kemerdekaan yang berontak. Tempo, 18-24 Agustus.

Abdullah T (1987) Islam, sejarah dan politik Aceh. Dalam: Islam dan masyarakat. Jakarta: LP3ES.

Abdullah T (1987) Pengantar. Dalam Alfian I (ed). Perang di jalan Allah. Jakarta: Pustaka Sinar Harapan.

Alfian I (2005) Refleksi tentang gempa-tsunami: Kegemilangan dalam sejarah Aceh. Dalam: Pirous AD (ed). Aceh Kembali ke Masa Depan. Jakarta: IKJ Press.

Alfian I (1997) Perang kolonial Belanda di Aceh. Aceh: Pusat dokumentasi dan informasi Aceh.

Alfian I (1999) Wajah Aceh dalam lintasan sejarah. Banda Aceh: Pusat dokumentasi Aceh.

Ali A (1999) Aceh dahulu, sekarang dan masa depan. Dalam: Widjanarko T, Sambodja AS (ed). Aceh merdeka dalam perdebatan. Jakarta: Citra Putra Bangsa.

Dhakidae D (2001) Aceh dan Papua, dua masalah kompleks dua jenis tawaran penyelesaian. Dalam Aceh, Papua, Jakarta: Akar permasalahan dan alternatif proses penyelesaian konflik. Jakarta: YAPPIKA.

Fukuyama (2002) Trust: Kebijakan sosial dan penciptaan kemakmuran. Yogyakarta: Qalam.

Lombard D (2007) Kerajaan Aceh zaman Sultan Iskandar Muda (1607-1636). Jakarta KPG (Kepustakaan Populer Gramedia).

Maklumat Ulama Seluruh Adjeh. Kutaradja 15-10-1945

Melalatoa MJ (2005) Memahami Aceh: Sebuah perspektif budaya. Dalam: Pirous AD (ed). Aceh kembali ke masa depan. Jakarta: IKJ Press.

Nugroho H (2004) Menumbuhkan ide-ide Kritis. Yogyakarta: Pustaka Pelajar. 3-23.

Reid A (2005) Asal mula konflik Aceh: Dari perebutan Pantai Timur Sumatera hingga akhir Kerajaan Aceh. Jakarta: Yayasan Obor Indonesia.

Reid A (2003) Perlawanan dalam sejarah Nanggroe Aceh Darussalam. Tempo, 18-24 Agustus 2003.

Salinan Naskah, Maklumat ulama seluruh Adjeh. Kutaradja 15-10-1945.

Siegel JT (2000) The rope of God. Michigan: University of Michigan Press.

Tiro H (1999) Demokrasi untuk Indonesia. Jakarta: Taplok Press.

TN (2006) [Komunikasi Pribadi] 23 Mei.

Veer PV (1977) Perang Belanda di Aceh. Banda Aceh: Dinas P dan K DI Aceh.

Zentgraaf HC (1997) Aceh. Dalam: Perang kolonial Belanda di Aceh. Alfian I (ed). Aceh: Pusat Dokumentasi dan Informasi Aceh. 